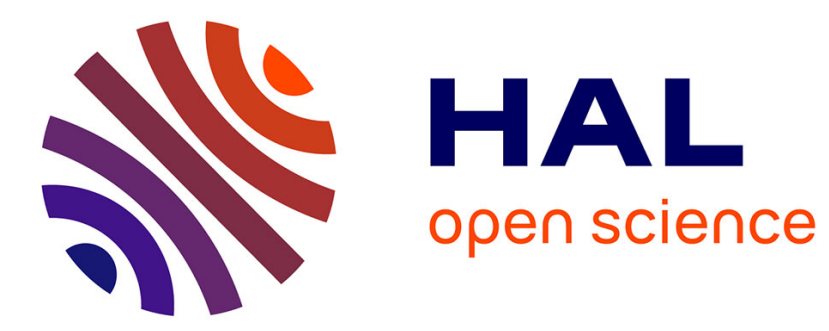

\title{
The Winner's Curse in Sports Economics
}

Wladimir Andreff

\section{To cite this version:}

Wladimir Andreff. The Winner's Curse in Sports Economics. Oliver Budzinski, Arne Feddersen. Contemporary Research in Sports Economics, 14, Peter Lang, pp.177-205, 2014, Political Economics, Competititon and Regulation, 978-3-631-64657-1. halshs-01243890

\section{HAL Id: halshs-01243890 \\ https://shs.hal.science/halshs-01243890}

Submitted on 20 Dec 2015

HAL is a multi-disciplinary open access archive for the deposit and dissemination of scientific research documents, whether they are published or not. The documents may come from teaching and research institutions in France or abroad, or from public or private research centers.
L'archive ouverte pluridisciplinaire HAL, est destinée au dépôt et à la diffusion de documents scientifiques de niveau recherche, publiés ou non, émanant des établissements d'enseignement et de recherche français ou étrangers, des laboratoires publics ou privés. 
5th ESEA European Conference in Sports Economics, Esbjerg, September 19-20,

2013

\section{The winner's curse in sports economics}

\section{Wladimir Andreff ${ }^{1}$}

Only very few markets in the sports industry resemble a fully-fledged competitive market on both supply and demand sides. Most markets are in a situation of imperfect competition, often with asymmetric information spread across a limited number of non anonymous competitors, and a differentiated product or service on sale (Andreff, 2012a). Thus the market structure turns out to be one of a monopoly (ex: the IOC over the supply of Olympics), a monopsony (a sports league in the labour market for talent), a bilateral monopoly (one public TV channel facing one sports league), or some sort of competition among the few (oligopoly, oligopsony). In such circumstances, prices, traded quantities and the level of transactions are not close to the equilibrium solution of a pure and perfect competitive market and may remain in lasting disequilibrium ${ }^{2}$.

When a sports entity (a federation, a league, a team, a player) operates as a monopoly on the supply side of a market, it usually adopts a strategy that aims at maximizing its monopoly rent without being accused (or sued) for the use of a discretionary economic power. One option for this monopoly is to fuel an intense competition on the demand side among those economic agents interested in its exclusive product or service, in particular when these competitors are few or not in a big number. A monopoly's tool often used is to create an auction-like situation or resort to an actual auction through which demanders will bid against each other up to the maximum price acceptable for the most optimistic bidder; this price determines the maximum monopoly rent that the sports entity could reach. Here comes the issue of a possible winner's curse whenever the market value of the object is unknown ex ante (before the bid), which often happens to be the case in the sports economy. Since the most optimistic among potential

\footnotetext{
${ }^{1}$ Professor Emeritus at the University Paris 1 Panthéon Sorbonne, Honorary President of the International Association of Sports Economists and European Sports Economics Association.

${ }^{2}$ For an inception to disequilibrium sports economics: Andreff (2014).
} 
bidders makes it to win the bid, there is a good chance that actual net revenues will be lower than anticipated by the winner.

When referred to by sports economists, the winner's curse is "the tendency of a winning bid to be in excess of the real value of the asset sold in the auction" (Sandy et al., 2004, p. 309). "Economists call this paradox - in which the 'winning' city is actually worse off than it would have been had it lost the bid - the winner's curse" (Leeds and von Allmen, 2002, p. 160). In the Fort's textbook glossary, one finds “winner's curse: in a competitive bidding situation with naïve and/or inexperienced bidders where there is a broad range of estimates of the value of the asset up for the bid, the highest bidder is certain to have bid well in excess of the actual expected value of the asset" (Fort, 2003, p. 474). This paper surveys the different situations in the sports economy where the winner's curse is likely to occur and raises the issue of how detect its very existence.

The paper reads as follows. First, the concept of the winner's curse is defined, and different variants of how a bid winner can be cursed are presented; prerequisites for the occurrence of the winner's curse are a monopoly facing few bidders endowed with asymmetric information so that one is the most optimistic and, as such, prepared to outbid all the others (1). One approach of the winner's curse in sports economics refers to bidding for hosting a megasporting event which always comes out with cost overruns for the winner (2). A second occurrence is when several cities are competing to host a same team location in a North American sports league: usually the winning city is cursed (3). An interesting case regards TV channels bidding for a sports league's broadcasting rights (4). Finally, a winner may be cursed in a specific way when several teams overbid each other for recruiting a same free agent player in North American team sports leagues or a superstar player anywhere (5). The conclusion briefly raises the issue of countervailing or alleviating the winner's curse. (6).

\section{What is the winner's curse all about?}

In any auction-type setting where the value of the auctioned object is uncertain but will turn out to be the same for all bidders, the party that overestimates the value of the object is likely to outbid its competitors and win the contest. This defines a common value auction ${ }^{3}$ where the

\footnotetext{
${ }^{3}$ A common value auction must be distinguished from a private value auction where each player's valuation is independent of those of the other bidders. In such auctions, the bidder cannot extract any information about his/her own value from the valuations of the other players. In a private value auction, knowing all the other bids in advance would not change one's valuation. At the time of the bidding, each bidder knows exactly what winning would be worth to him/her, but does not know what it would be worth to others.
} 
item to be sold has a single objective value for all bidders, but this true value is unknown. Each bidder has to guess the item's true value at the time of bidding on basis of the information that is available, and without knowing the other's guesses. The items won, however, are more often than not those whose value has been overestimated. The winner's curse exists in these common value auctions when bidders fail to account for the fact that the winning bidder's valuation of the object is an upward-biased estimate of its true (unknown) value. Auction winners are cursed by having paid more for investing in an item than its true value. Thus, there is adverse selection in this outcome, and the bidding process results in wins that produce below-normal or even negative returns, contrary to rational investment decision. Thaler (1994) stresses the asymmetric information across bidders, which leads to an extreme form of the winner's curse in which even any positive bid yields an expected financial loss to the winner. Moreover, an increase in the number of bidders implies that to win the auction, the bid must be more aggressive. The degree of a winner's overbid and hence the magnitude of its loss generally rises with the number of bidders. Yet the presence of more bidders also increases the chance that the winner will have overestimated the value of the object on sale.

\subsection{Four variants of the winner's curse}

The winner's curse hypothesis was first advanced by Capen et al. (1971) to explain the low returns on investments to companies engaged in competitive bidding for oil and gas leases. The impression was that winning bidders had paid too high a price for oil and gas leases (Gilley et al., 1986); in other words, they had been cursed. Indeed, they have paid an auction price higher than any likely market price and they will bear too high a cost to be recouped by the revenues of their investment. This is the core example of a winner's curse.

A second variant, now the most widespread in economic literature, is rooted in financial markets (Kagel and Levin, 2002). The winner's curse assumption is namely utilised to explain the share value underestimation in initial public offerings and the positive initial returns earned by investors on newly issued equities (Levis, 1990). When going alongside with non transparent or not unveiled information about risks involved in the issuance of new financial products (derivatives, CDOs, CMOs, etc.), then followed with their further securitisation, this second variant of the winner's curse combines with a third one - the sale of 'lemons' - in providing new insights about the current financial crisis (Andreff, 2013). This second variant can hardly apply to sports objects so far. 
A third variant of the winner's curse has been found in second-hand markets, primarily in the market for 'lemons'. Akerlof (1970) has demonstrated that in a context of information asymmetry the market leads to adverse selection and the purchaser is cursed. When information about quality is scarce and asymmetric, namely as regard a player's talent, this third variant of the winner's curse makes sense in sports economics.

A last variant of the winner's curse fits in a public choice approach. The winner is cursed after deliberately underestimating the cost - and/or overestimating the outcome - of a public investment decision. Winning the bid and getting those resources or funds allocated by a central body to decentralised operators or producers, the winner will pay the price of its initial cost underestimation with long-lasting cost overruns. This typical overbidding process has plagued for decades the former centrally planned economies (CPE) that allocated a national centralised investment fund across state-owned enterprises (Dyker, 1983). The central planning agency was standing in a monopoly position for supplying investment funds through an auction-like process while decentralised enterprises were overbidding each other for obtaining these funds.

Due to information asymmetry about investment projects - each project is well-known by the applying enterprise, not by the central planners -, the whole auctioning process regularly led to enterprise 'cheating' on information about their production capacity, overinvestment (excess fund allocation), adverse selection of investment projects and unexpectedly long completion duration of selected projects. If information is asymmetric, enterprises applying for investment funds are incited to 'cheat' through underestimating their actual costs, and overestimating their actual benefits. The winner's curse lies therein. The applicant enterprise that wins the bid due to overbidding based on such under/overestimation is cursed: due to informational cheating, it has submitted an infeasible project and, in practice, it will not be able to complete it within the deadline, and at ex ante announced costs/benefits.

For each investment project $k$ a discounted net benefit (its social profitability) was calculated by the enterprise as:

$$
B_{k}=\sum_{t=0}^{N} \frac{R_{k t}-C_{k t}}{(1+a)^{t}}
$$

where $R_{k t}$ stands for all revenues derived from the investment over its lifetime (from $t=0$ to $N), C_{k t}$ stands for all investment costs $\left(C_{k t}=C_{0}+C_{t}+C_{f t}\right.$ with $C_{0}$ the initial investment cost, $C_{t}$ the cost of all further annual investment 'slices' in the case of a multiannual investment, and $C_{f t}$ the operational cost of the equipment over its lifetime) and $a$ is the national discount 
rate fixed by the central planners. However, cheating on investment projects tended to be the rule rather than the exception in CPEs (Kornaï, 1980; Andreff, 1993) because:

. Enterprises announced an investment $\operatorname{cost} c_{k}$ for project $k$ and not the actual cost $C_{k}$, with $c_{k}<C_{k}$, in order to augment their chance of obtaining investment funding from the planners.

. Enterprises declared very optimistic - often completely unrealistic - completion duration for project $k$; Soviet economies were famous for their unfinished investment building sites resulting from unattainable completion duration.

. Enterprises anticipated overestimated revenue from investment: $r_{k}>R_{k}$, with $r_{k}$ the ex ante announced revenues and $R_{k}$ the actually expected revenues.

A consequence of investment cost underestimation and investment revenue overestimation is that the social profitability of an investment project $k$ sent by an enterprise to the planners was higher than its real social profitability: $b k>B k$.

Since all enterprises adopted such strategic behaviour, central planners were confused, and unable to make rational decisions about how and to whom to allocate the national investment fund. Facing a myriad of fabulous investment projects, planners had a tendency to inflate the number of financed projects. Indeed, all the projects submitted to planners were unrealistic, exhibiting an extraordinary social profitability, unbelievably low costs and a very short completion time. In such a confused situation, adverse selection was the most common outcome and inefficient or low-efficiency investment projects were financed. Generally, enterprises more often cheated by underestimating costs and completion duration than by overestimating investment revenues.

The rest of the paper will cover different sporting objects which are used to be allocated through auction or an auction-like process in a context of information asymmetries across the bidders facing a sporting entity with a monopoly over the supply of these objects. In these circumstances, the winner's curse is likely to occur and materialise in financial loss.

\subsection{The winner's curse eventually expresses the monopoly power of a sports entity}

When the winner's curse is only understood as the result of irrational bidders' behaviour, i.e. overbidding each other, it is comprehended as a demand-side triggered mechanism. In the sports industry, it happens that several TV channels are eager to broadcast a same sport event while just one sport team, league or federation is the only supplier. Then for TV channels there is no other way than overbidding to obtain the broadcasting rights. If several sport teams are willing to recruit a same player in the labour market for talent, they have to trade off 
between abandoning any claim and overbidding the claims of competing teams. The winner's curse materialises a typical supply side monopolistic behaviour. One implication of a monopolistic supply (which may even be a global monopoly, think of IOC or FIFA) is that, on the demand side for an auctioned object, there must be more than one bidder for the winner's curse to occur. If there were only one candidate city applying to host the Olympics, the winner's curse could not occur; while as soon as there is more than one candidate, they have to overbid each other. In North American team sports leagues, if a team faced only one municipality eager to host its games in a city's stadium, no way for the winner's curse; but if at least another one municipality would like to host the same team, then the latter is in a monopoly position and can trigger an overbidding process between the two cities.

In an auction or auction-like process, it is the interaction between two series of asymmetries that is crucial for the occurrence of the winner's curse and its usual consequences such as overpricing, cost overruns, adverse selection, delayed project completion, and financial loss: first an asymmetry in the number of traders on both market sides with just one seller and several purchasers and, second, information asymmetry between the seller and purchasers as well as across the latter. At the end of the day, it is always a question of a single sporting actor on the supply side which uses its monopoly power ${ }^{4}$ to play any demander against the others, thus compelling them to overbid. Therefore, the winner's curse always ends up with an overpriced purchase for the winner since this price contains a monopoly rent ${ }^{5}$ and is higher than equilibrium price in a free competitive market.

To sum up, to witness the winner's curse occurring in the sports industry requires: $a /$ a monopoly position of a sports entity on the supply side of the market for a sporting object ${ }^{6} ; b /$ several rather aggressive demanders of this object, but not too many numerous so that an auction(-like) process can easily be organised by the sporting monopoly (the demand side is oligopsonistic); $c$ / this is a common value auction since the true value of the sporting object is unknown to all bidders; $d /$ as a consequence of $a$ and $b$, the market structure in which occurs the winner's curse is an oligopsonistic monopoly; $e /$ a second consequence is information and power asymmetries between the sporting monopoly and potential bidders; $f /$ information asymmetries across the bidders leads one of them to be the most optimistic and to outbid the

\footnotetext{
${ }^{4}$ As Vrooman (1996) puts it: "Information asymmetries create the bias [the winner's curse] only because the auction process exists in a monopoly environment".

${ }^{5}$ In an auction process with overbidding, bidders themselves determine the level of the monopoly rent through their repeatedly increased reservation prices, contrary to a textbook monopoly behaviour where the monopolist shortens quantities in supply in view of raising its supply price.

${ }^{6}$ Vrooman (2000) correctly stresses that, in the case of the winner's curse, information asymmetry is a necessary, but not a sufficient condition for the overbidding.
} 
others; $g$ / information asymmetries across the bidders often pertain to the quality of the supplied sporting object even without a cheating behaviour of the sports entity - like in a market for 'lemons'.

\subsection{How verify the very existence of the winner's curse?}

A major difficulty with the winner's curse concept consists in testing its very existence. The most common effect for a cursed winner is that he/she will pay ex post much more than expected ex ante, and lose money. In a nutshell, some sorts of cost overrun or overpricing are simple and general indices of the winner's curse: a city hosting the Olympics exhibits a local cost significantly higher than announced in the candidature file; a municipality subsidises a host team so much that it jeopardises its public finance, then increases local taxes; a TV company pays an excess price for broadcasting rights which may jeopardise its financial balance or even its own existence; overpaying some players, a team loses control over its payroll, and its salary cost overruns may drive its accounts into the red. One can infer from the different below-described cases of the winner's curse some indices that would enable to spot its existence resulting from the auction for hosting mega-sporting events, a professional sports team location, broadcasting rights, and those traded players in high demand.

In any case, the most convincing proof of the winner's curse would be to calculate that a significant negative difference is observed between ex ante and ex post net social outcome of a mega-sporting event (a host team, TV rights, a player) in comparing the results of an ex ante and an ex post cost-benefit analyses of a same sporting event (host team, etc.). Unexpectedly higher net social cost or lower net social benefit would confirm the winner's curse hypothesis that is if ex post net social cost is significantly higher than ex ante net social cost or if ex post net social benefit is significantly lower than ex ante net social benefit. A major difficulty with this criterion is that an ex post cost-benefit analysis usually is not available or published after each mega-sporting event (hosting a team, paying TV rights fees, player recruitment). Hence, proxies are required; they are listed with the four types of the winner's curse surveyed below.

\section{Corrigé à partir d'ici}

\section{Bidding to host a mega-sporting event: the winner's cost overruns}

There is some similarities between a centralised auction for investment funds in a CPE and the functioning of an auction whereby the Olympics are allocated to a bidding city (Andreff, 
2012b). With the Olympics, the IOC publicises the task of hosting and organising the next Games within a precise deadline then it calls for projects proposals. These proposals are not applications for IOC funding; rather, cities are candidates for raising funds from different sources in order to cover the cost of those investments required to host the Games. At the end of an auction, which usually takes several years, the IOC allocates the right to host the Olympics to the most interesting city project. However, the fact that the object of such an auction is not to obtain finance allocated by the IOC but to win the status of being the next host city of the Olympics does not reduce the risk of a winner's curse. A city that wants to host the Games commits itself a heavy investment over a six- to seven-year period and then hopes to benefit from the 'Olympics host city' label which provides a unique capacity for collecting and mobilising finance.

\subsection{Candidate cities actually (though inadvertently) bid for cost overruns}

The objective of the IOC, in a monopoly position to allocate the Games, is to elect every fourth year a host city for the Summer Olympics and the Winter Olympics with the expectation that bidding cities will provide projects including all the required facilities and commit themselves to adhering to an operational budget, which is a minimal precondition for a city to be selected. A complementary objective certainly is the best possible quality of the Games which consists of a guarantee of well-functioning and secure sports contests (quality of sporting equipment, distance between Olympic venues and the Olympic village, and so on), an excellent hosting quality (Olympic village, transportation, hotels), overall security, impressive opening and closing ceremonies, high-quality media and telecommunications and, nowadays, an environmental quality, all prerequisites according to the 20 chapters contained in a candidature file. Thus, if the IOC is maximising something, it is the overall quality of the project which must benefit from worldwide media coverage, leave a grandiose image of each Olympiad, and an unforgettable memory and indelible marks on the host city landscape. With a view to obtaining a grandiose project, it is in the IOC's interest to pave the way for or even fuel overbidding across bidding cities. This is what it clearly started to do after the single candidature of Los Angeles for the 1984 Olympics.

It is more than likely that the cost of the Olympics is not a decisive criterion in the voting of the 104 IOC members. Furthermore, the criterion of minimal cost to some extent clashes with maximising the desired extravagant quality of the Games. A proof of such a contention is that the IOC often selects the most expensive rather than the cheapest project (see Table 4.1 in 
Andreff, 2012b), which means both adverse selection in terms of cost, and that the winner's curse is at work.

The objective function of bidding cities is crystal clear and consists in obtaining the right to host the Games. Therefore, each bidding city must promise fixed quantities of sporting facilities requested by the IOC and a variable quantity of non-sporting infrastructure, focusing on their excellent quality since it will be selected or not on these aspects of its candidature. Before Montreal 1976, investment cost and the $\mathrm{LOOC}^{7}$ operational budget did not matter that much. Since then, and after Los Angeles 1984 demonstrated that the LOOC can end up in the black, the cost dimension of candidatures has become much more significant, though not the major decision criterion of IOC voters.

The primary interest of bidding cities is to maximise (and focus on) the qualitative components of their candidature, thereby encouraging ambitious project proposals. After 1984, bidding cities started to take an interest in also demonstrating reasonable or even low costs in parallel with the supposedly unbelievable quality of their candidature. The only way to reconcile an extravagant project with costs that are not exorbitant is, explicitly or implicitly, to cheat, that is, to communicate and to complete the candidature file on the basis of costs that are underestimated by different means (omitting the VAT, lowering the Paralympics budget, and so on). All in all, it is in the interest of the bidding cities to overbid upward with respect to the quality and downward with respect to the publicised cost of their project. Such a strategy compares with that of rival enterprises struggling for the allocation of investment funds in a CPE except that cities are seeking to be awarded the Games, because it is a precondition for mobilising huge finance necessary for hosting the Olympics. Thus, rival bidding cities are in sync with the principal objective of the IOC, which is to balance outward extravagance with the appearance of reasonable cost, but the host city is cursed.

The parallel with enterprises in CPEs cannot exactly be extended to the completion duration of investments since this was mandatory, but almost never met, in Soviet- type planning. Yet, the completion duration is mandatory and cannot be circumvented in hosting the Olympics it is not feasible to start up Olympics sports contests if the stadium is not completed - but the IOC's recurrent worries about delayed Olympics building sites can be used as a control variable of the winner's curse. Building delays usually generate cost overruns when it comes to rushing in order to stick to the deadline. Revising building costs upwards (thus revealing

\footnotetext{
${ }^{7}$ Local Olympics organisation committee.
} 
the initial cost underestimation) or giving up some Olympics building to curb skyrocketing costs are also relevant signs of the winner's curse.

Another revealing factor is when the LOOC or the host city obtains extra finance or extra public subsidies, for instance, from the government. A financial deficit or an ex post lower financial surplus than expected by the LOOC provides further proof of the winner's curse while a sanction of the latter is a bidding city budget deficit which must be covered with a specific post-Olympics taxation.

Information asymmetry is crucial in the genesis of the winner's curse. A bidding city knows its candidature project down to the tiniest detail, so it is able to communicate in such a way as to emphasise specific aspects of the file, in particular its supposedly extraordinary quality. In contrast, this in-depth knowledge of the candidature file allows the bidding city promoters to play down those less exciting characteristics of the project, namely excessive costs, stark security issues, negative externalities and a possible crowding-out effect. An economic impact study is instrumental in highlighting the best features and blurring the lesser ones. The IOC cannot have a similar in-depth knowledge (information) about each bidding city project and cannot control how accurate or fallacious is the information delivered in the application file, namely about actual costs, externalities, and so on. The Olympics site visits by the IOC representatives are not enough to compensate for information asymmetry between bidding city promoters and the IOC voters.

The allocation of the FIFA World Cup is also plagued with the winner's curse although Sturgess and Brady (2006) contend that evidence is rather mixed. However, Preuss and Schnitzer (2013) underline that the budgets of local organisation committees (LOC) are used as a strategic bidding tool; again given an asymmetrical availability of information, FIFA faces an adverse selection problem. The LOC conceals certain facts (the real costs of staging the World Cup) from FIFA until the hosting agreement is signed. Thus, the bidding committees strategically underestimate their LOC budgets and meet financial problems after being awarded the World Cup, as it was the case in South Africa 2010. Bidding committees face a dilemma because they have to offer FIFA a good (often too low) LOC budget to look more attractive than other candidates. This dilemma translates into a winner's curse for the LOC that outbids the others.

\subsection{Indices of the winner's curse when hosting a mega-sporting event}


A series of indices has been featured for verifying the existence of the winner's curse with regards to cities bidding to host a mega-sporting event (Andreff, 2012b):

1. Cost overruns: A difference between ex ante cost in the candidature file and ex post cost reached on the sporting event's opening day or later exhibits the winner's curse. Given that over a period of six or seven years between the allocation and the opening of a mega-sporting event there is some inflation in any country and that upward cost revisions happen a more or less clearly defined date and are usually published in current prices, one can accept as a proof consistent with an existing winner's curse a difference of at least 30 per cent between $e x$ post actual and ex ante anticipated cost. The data to be found are the initial cost in the candidature file, the actual cost at the moment of the opening ceremony and, if one can circumvent data paucity, the actual final cost overall. The example of cost overruns in all the Summer Olympics but one - Los Angeles 1984 when there was just one candidate city and thus neither overbidding nor a winner's curse - is exhibited in Appendix 1.

2. Ex post revisions in the mega sporting event's project: A second index can be used when some significant revisions occur in the project of a mega-sporting event between the dates of allocation and opening ceremony. For example, the appearance of a new building in the project which was not included in the candidature file is an explicit index of an initial cost underestimation. Similarly, an upward revision of expenditures linked to one sporting facility or non-sporting infrastructure project can also reveal the existence of the winner's curse. Or, when a building that was planned in the candidature file happens to be cancelled, this also reveals an initial cost underestimation: due to the latter the bill skyrocketed and the host city has no other way to curb cost overruns than by giving up some building described in the candidature file.

3. Delayed completion of a required investment: The completion dates of different sporting facilities required by the event which are mentioned in the candidature file simply cannot be missed. Thus, a delayed completion of such investment merely translates into a time lag between expected and actual completion dates, and in a subsequent final rush in the last weeks before the opening ceremony to complete the unfinished building. A final rush at the very last minute always inflates the actual investment cost.

4. Extra public subsidy or extra public finance: If the cost of hosting a mega-sporting event was initially underestimated, one way out for local organisers and the host city is to bargain and obtain additional public finance or an extra subsidy, for instance from the government or from some regional authorities. 
5. Host city fiscal deficit and debt: When the extra cost of the mega-sporting event project results in a heavy financial burden for the host city its budget plunges into a fiscal deficit and a public debt that has to be repaid over time. The same index may register the transformation of ex ante local organisers' surplus into ex post deficit.

6. A disappointing number of 'foreign' visitors: When the number of 'foreign' (that is, coming from outside the host city or region) visitors is lower than expected, then revenues will be lower than expected and, possibly, will increase financial losses.

\section{Bidding to attract a sport franchise: is the host city worth off?}

In North American professional team sports leagues, each time a franchise owner seeks a new location for its team several cities actually or potentially bid to be the host. Cities eager to promote economic development and image compete for hosting the team, and inadvertently find themselves victims of a bargaining process whereby all cities experience an auction-like bidding game (Rosentraub and Swindell, 2002).

\subsection{The most optimistic bidding city is cursed}

When looking for a location a team owner is in a monopoly position and may abuse of its power (Quirk and Fort, 1999); cities are the bidders and the prize for the winner is to obtain the franchise being located in its municipal area. Bidders in such an auction-like bargaining process are played against one another by the team owner. Each competitor bases its bid on how much it expects the team to be worth, and submits the bid to the league. If a city overestimates the benefits the team will bring, it overbids for the franchise it would have been better off losing. The key of the winner' curse is that not all cities have the same expectations; only the most optimistic bidder wins the prize. When a city wins the bid this basically reflects its optimism about the unknown value of the team due to information asymmetry.

The team owners who control the process of bidding for teams place cities in sequential and simultaneous bargaining games (Dixit and Nalebuff, 1991). This sequential game starts with a negotiation between a team and a single city, frequently the team's home city. The team puts demands on its host city for improved lease terms, stadium renovation, increased subsidies, and publicly funded new stadiums and arenas. The best strategy for a city is to simply add an increment to the previously accepted subsidy and thus overbid potentially competing cities. If its demands are not met, a team owner can point to other cities that may offer a large stadium 
subsidy as a potential to move if the incumbent host does not help. Conversations with other more cooperative or pliant municipalities will begin and here comes the simultaneous game. These combined games create an auction-like bidding for each city and trigger the likely winner's curse of providing a subsidy for the jurisdiction whose bid is accepted.

The bid for a franchise is conducted in a context of asymmetric information about the value of public investment and the bargaining strength of the team owner. Winning such a bidding game paves the way to the winner's curse when the returns on a municipality public investment for expected economic development opportunities fail to exceed the costs of the package that won. Subsidies will not generate economic development if all they do is to keep an existing team from moving to another location. With asymmetric information, the outcome is a misrepresentation of the costs and benefits of the options available that derives into significant cost overruns (Blair and Swindell, 1997): the winning city is cursed.

North American teams and leagues hold monopoly positions over entire cities. Cities compete over the right to host a franchise but do not participate in a formal market in which they directly pay for a good or a service. They pay the right to host teams by building facilities for them, providing them revenue guarantees, and allowing them to capture revenue from parking, concessions, and luxury boxes. Limiting the number of franchises enables a league to act as a franchise monopolist and maximise its members' monopoly rent. A league facilitates the monopoly power of team owners by restricting the number of teams in the league; this artificial restriction favours teams in their negotiations with host cities. In order for teams to exert their monopoly power over cities, the league should not place teams in every viable location. The size of the league relative to the number of cities that want to host teams plays a key role in the bargaining strength of the teams with cities. Restricting the number of available franchises, a league can drive up the price cities pay to attract a franchise or to retain one they already have. Because owners, acting as leagues, have controlled the location of teams so well, the cities are at a bargaining disadvantage and eventually are cursed.

As state and local governments are understandably reluctant to subsidise multi-million dollar sports enterprises, the teams threaten to leave for one of the viable locations its league has kept open. When a team contemplates a move, its owner usually cites the need for more skyboxes, lower lease payments, and better practice facilities. The implied threat in such statements is that some other city is offering such facilities. Given that leagues manage locations to keep teams the only game in town, a local government must deal with its current tenant or lose a team and hope that it can woo an unhappy owner or gain a team in the next expansion round. Hosts usually are unable to appeal some other team to replace their current 
team when it has gone. North American team sports leagues provide a number of famous stories of franchise relocation threats ending up with skyrocketing subsidies that materialise the winner's curse.

\subsection{Indices of the winner's curse when attracting a sport franchise}

The winner's curse in attracting a sport franchise in North American team sports leagues may be checked with different indices, often mentioned in the literature, in particular:

1. The amount of subsidies for new sports facilities.

Another index could be envisaged which is a team's relocation move since it always follows up preceding negotiations, bargaining and overbidding. However it is not a comprehensive index because such bargaining and overbidding may end up with a city keeping its franchise, and thus no move: remaining the host, a home city may be cursed as well.

2. An actually luxurious increase of the current subsidy devoted to a stadium or arena. Since subsidies are paid at taxpayer expenses, the host city is cursed but eventually local taxpayers have to pay the bill through the municipality budget whatever their willingness to pay for the stadium. They are cursed either.

3. Cost overruns during the implementation of a blurred municipal project for stadium improvements, new parking places, the placement of hubs for airlines, and so on. The blurred municipal project misrepresents the real costs in order to have it accepted by local legislative bodies or voters. The magnitude of the winner's curse is in proportion of cost underestimation.

At the end of the day, a city is definitely cursed if, after attracting a franchise in its urban area: 4. Local economic growth slows down or stagnates instead of being boosted by municipal subsidies and/or a new stadium.

5. Urban development and restructuring is stagnant despite the forecast that a new stadium or stadium improvements will provide an opportunity of urban renovation.

6. Stadium attendance actually is lower than expected during the bargaining negotiations about the franchise location.

Some credibility is provided to the last three indices, though they are not so often calculated, by a number of studies (Baade et al., 2008; Coates, 2007; Johnson and Whitehead, 2000) which have exhibited that hosting a new franchise can create only a negligible positive net economic impact, when not negative, in North American urban areas. 


\section{Television channels bidding to acquire broadcasting rights}

In recent years the number of television (TV) channels involved in sports broadcasting has increased substantially. The process started up in the 1970s in North America and in the 1980s in Europe. This development has triggered a fierce competition between TV companies and dramatically increased the broadcasting rights on the most attractive sports. Here, the winner's curse results from staging an actual auction and not an auction-like mechanism as in the franchise location story.

\subsection{When the winner's curse may kill you}

Competition between TV companies to broadcast a same sport event supplied by a single sports organisation (team, league, federation) - thus in a monopoly position - has inflated the broadcasting rights fees. English auction and sealed-first bid, or combinations of them, have been the most common procedures since sports broadcasting rights started to be auctioned (Solberg, 2006).

In an English auction, the process starts with a low bid, which is then raised successively by just small amounts over the previous bid until one bidder wins. Meanwhile all other bidders give up when the bid rises higher than their own valuation and their maximum reservation price. The winner is the TV company with the highest bid which pays the last reservation price it has claimed to pay. The bidding procedure ends up when the price reaches just above the valuation of the bidder with the second-highest valuation. The narrower difference between the last two bidders' valuations, the higher the final price. The risk of the winner's curse is very high since a TV company has no information about the actual maximum valuation of other competitors and thus must overbid to increase its information about rivals' valuation until the price reaches its own valuation.

In a sealed-first bid procedure, each bidder submits one bid without having any information on the rivals' bids. The highest bidder acquires the rights. A TV company's bid is a function of its own valuation and its prior beliefs about the rivals' valuations. Since the bids are kept secret, risk-averse bidders are not provided with increasing information to predict the value as during the process of an English auction. Information secrecy works to the seller's advantage, in particular when there is a wide gap between the highest and the second highest bids. The risk of the winner's curse is even higher than with an English auction since the winner never knows the (sealed) reservation price of rival TV companies. Indeed, the bidder with the 
highest valuation faces two potential traps. Bidding too low a price, the bidder will be running the risk of missing out on a deal that could have been profitable. Countervailing this risk, each bidder is in danger of bidding more than necessary, and thus being cursed ${ }^{8}$.

With both auction procedures, the broadcasting rights have become extremely expensive and have increased so much that the TV company that acquires them is hit by the winner's curse. Quite a number of sports rights deals have ended up being unprofitable for the TV network (Solberg and Hammervold, 2008) which has translated into financial losses for the TV channel that has won the bid. Several broadcasters have been hit by the winner's curse because they discovered too late having overpaid for the rights and were thus unable to make the acquisition economically viable. In some cases, such as ITV Digital, the winning TV channel is so much cursed that it goes bankrupt (Buraimo, 2006); a same way out occurred with the German Kirch Media. Take care, the winner's curse may kill you!

In both English auction and sealed-first bid the actual winner definitely is the monopolistic seller that is the sports organisation which offers its broadcasting rights. The higher rights, the larger monopoly rent that falls to the seller. In general, the purpose of staging an auction is to maximise the seller's proportion of this rent. As in the two previous cases - bidding for a sporting event and a sport franchise - information and its distribution among the bidders is crucial. If there is not much information on which TV companies can build their subjective valuations of income (derived from fans, advertisers, etc.) to be earned from a sport broadcast, then the most optimistic - and therefore wrong - highest bidder will win and be cursed (Fort, 2003).

Moreover there is a risk of excess supply if too many TV channels broadcast too many similar sport programmes simultaneously. Their uncoordinated actions can create severe financial problems. The demand may also fluctuate for those broadcast games after the bids are submitted $^{9}$ : it is impossible to estimate the income from broadcasting accurately when sports events will take place sometime in the future. Here, the winner's problem is that it realises this too late (Gratton and Solberg, 2007). Income turns out to be lower than expected while it is impossible to reduce sunk costs. The winner's curse is more probable when the auction has

\footnotetext{
${ }^{8}$ In some circumstances, some TV companies may enter the auction mainly to push the price up. The reason for this is to weaken the ability of the winner to submit bids on the next occasion a package of sports rights is being auctioned (Gratton and Solberg, 2007).

${ }^{9}$ Blair (2012) stresses that the demand for advertising slots is far more unpredictable than broadcasting costs (including TV rights) since these slots cannot be sold before bidding on and being awarded the broadcasting rights. The winner's curse may be due to some cause reducing the demand for advertising in general (ex: an economic recession) or for a particular sporting event (Gratton and Solberg, 2004).
} 
to end up before anyone knows when or where a sport event will occur and/or which are the sport teams that will qualify, as for instance with the FIFA World Cup final stage.

To countervail the risk of the winner's curse TV companies tacitly collude or openly merge in such a way as to balance the sporting seller's monopoly power with a monopsony power ${ }^{10}$. Such countervailing strategy curbs the inflation of broadcasting rights fees whereas its absence fuels a fee skyrocketing trend. For example, in the French market for football broadcast, the merger between Canal Satellite and TPS came out with moderating the rights fees inflation. But if a newcomer enters the market and thus increases the number of aggressive bidders, broadcasting rights fees and the monopoly rent of the sports organisation are likely to inflate. This is what occurred in the French market for football broadcast in 2012 with the entrance of Be In (an Al Jazeera subsidiary) outbidding Canal +.

Competition among TV companies can be cooled down with de-packaging the broadcasting rights on sale. After BSkyB obtained the whole package of the English Premier League football broadcasts for 2004-07, the European Commission started recommending that broadcasting rights on a single sporting event must be split and sold into different sets (live, highlights, first league games, second league games). This EU policy clearly aims at countervailing the sporting sellers' monopoly position and narrowing their rent through depackaging. This is not to say that consequently the winner's curse would disappear, but the financial cost for cursed TV companies would be lower with de-packaged broadcast deals than with acquiring the whole package of TV rights. Any move back to re-packaging the rights would reinforce the seller's monopoly position and the impact of the winner's curse.

A last option for a TV company is to undertake a vertical integration (Stotlar, 2000) with a sports team or a sports league ${ }^{11}$ whose sporting events are targeted for broadcasting, in view of benefitting from a so-called toehold effect. A toehold is an asymmetry between the bidders in an auction, such as one bidder acquiring an ownership stake in the object being sold. One bidder toeholds work by multiplying up the potential of the winner's curse for other rival bidders. There is strong evidence that acquiring a toehold - even a very small one - can

\footnotetext{
${ }^{10}$ If at the end of the day there is just one potential bidder facing a monopolistic seller then emerges a bilateral monopoly market structure (Sandy et al., 2004).

${ }^{11}$ Some examples of partial or total share ownership by a TV company in a sports organisation are (or have been): TBS in Atlanta Braves (MLB), Atlanta Hawks (NBA) and Atlanta Thrashers (NHL), News Corporation in Los Angeles Dodgers, Walt Disney in Anaheim Mighty Ducks (NHL) and Anaheim Angels (MLB), Cablevision Systems in New York Kicks (NBA), New York Rangers (NHL) and New York Liberty (WBA), Comcast Corp in Philadelphia 76ers (NBA), Philadelphia Flyers (NHL) and Philadelphia Phantoms (WBA), UFA Sports in Borusia Dortmund, Hamburg SV and FC Nuremberg, Mediapartner in Milan AC, Granada in Arsenal and Liverpool, NTL in Aston Villa, Newcastle, Middleborough and Leicester City, M6 in Girondins de Bordeaux, Canal + in Paris-Saint-Germain and Servette de Genève.
} 
confer a huge competitive advantage on a bidder in an auction (Harbord and Binmore, 2000). In standard auctions, a bidder with a toehold is virtually guaranteed to win the auction, and at a lower price than it otherwise might have paid. This interacts in alleviating the winner's curse, causing other bidders without a toehold to reduce their bids for fear they have overbid in a contest with a competitor which already has an insider advantage.

A toehold is a TV company's attempt to divert a part of the monopoly rent from the sports organisation in lessening or expelling competition for TV broadcasting rights. A broadcaster ownership of a sports team or league is anti-competitive when it relies on a toehold effect (Cave and Crandall, 2001) but it is a major hindrance against the most extreme impact of the winner's curse on a TV company benefitting from the toehold. Then a TV company would bid for a common value object of which it is already partial owner and would correspondingly reduce its outlay on the purchase of TV rights.

\subsection{Indices of a winner's curse in a bid for broadcasting rights}

Bidding for broadcasting rights over a given sporting event is not an auction-like process but a genuine auctioning process. Indices that a winning TV channel is cursed are:

1. A very swift increase in TV rights fees on a same sporting event from one broadcasting contract to the next one.

2. Financial loss endured by a TV company on a broadcast deal: the income derived from televising a sporting event do not cover sunk costs of producing the broadcast, including those rights paid after outbidding competing TV channels.

3. A post-bid bankruptcy which exhibits ex post that a TV channel could not afford the bid which it won due to overoptimistic valuation.

4. Too many unknown and uncertain details about the date, the place and the participants (qualified teams and athletes) of a sporting event which falls adrift into unexpectedly low broadcast revenues and high costs ending up in a loss.

5. Outbidding newcomers which enter the broadcast market for a given sporting event increase aggressive competition on the demand side and thus make the winner's curse more likely to happen.

6. TV rights re-packaging for a given sporting event, if any, in reducing the number of products on sale in the face of a given number of TV channels leads to increased competition that triggers TV rights fees inflation and thus a greater likelihood of the winner's curse. 


\section{Teams bidding to recruit free agent and superstar players}

The former reserve clause in North American leagues and the former transfer system in European leagues effectively prevented a player from offering its services to another team in the league at any price. No auction-like mechanism could emerge. In the 1970s, veteran players obtained the status of a free agent in North American leagues while in the postBosman era (1996 on) players gained a free international mobility in European leagues. Then team owners started bidding in a free market for players, and often competition across teams for a same free agent or superstar ${ }^{12}$ player drifted into overbidding.

In the labour market for talent, team owners are the bidders and free agent or superstar players are sellers of the right to use their talent. For each sale the free agent or superstar player is in a monopoly situation over its talent rights as soon as this player is not substitutable on the pitch $^{13}$ (Andreff, 2014). The prize is for the winning team to recruit a player despite other teams' bids. The player auctions the right to use its talent and sells it to the highest bidder while the bids are determined by each team's estimate of the marginal revenue product associated with a given player after looking at its past performance and characteristics (points scored, age, height, experience, etc.). The team that expects the highest marginal contribution of a given player to its revenue offers the highest salary bid. If information about players' characteristics is limited, uncertain and asymmetric across teams, preconditions for the winner's curse are therein. In the context of North American team sports leagues, the winner's curse pertains to trading free agent players whereas in European professional team sports leagues where there is no draft, all players being tradable, the issue is more with players in a monopoly position over their scarce (high quality) talent rights, i.e. superstars.

\subsection{Recruiting a free agent ... that reveals to be a 'lemon'}

With regards to free agent players in North American leagues, overbidding is due first to an inherent element of uncertainty in evaluating a player's future marginal worth. Estimating a given player's marginal impact on team revenue entails estimating the player's contribution to

\footnotetext{
${ }^{12}$ Fort (2003) even contends that rookies, untested at the professional level, are often paid more than established veterans and are not worth their huge bonuses and starting salaries. Teams are cursed with the rookies as well. Michael Jordan was one of the most obvious cases in point. Overpayment of NBA rookie salaries is successfully tested in Eschker et al. (2004).

${ }^{13}$ A major aspect of a superstar player is precisely that its substitution elasticity is zero: it can only be substituted on the pitch by a 'superstar proxy' or a second best player having not the same impact on scoring, the sporting outcome, and drawing attendance.
} 
team wins, hitting and pitching potential (in baseball), scoring, fan appeal, and so on. Presumably the bidders overestimate sometimes and underestimate sometimes. Given this uncertainty, the auction process necessarily biases the winning bid upwards when many bidders participate. Increasing the number of bidders magnifies the overestimation bias (Cassing and Douglas, 1980). As a result free agents are likely to be overpaid, and the winning team is likely to be cursed. Cassing and Douglas argue that there will be a tendency to acquire a biased set of free agent players, those for which buying teams have overestimated the value and overpaid, thus the authors' contention of the winner's curse. The bids will not mirror the true worth of the player; a team that values it correctly has a poor chance of signing a player compared to a team that overestimates the player's value. Conclusion: free agents are really paid too much.

How explain this since a sports league is a monopsony in the labour market for talent? A first assumption (Fort, 2003) is that most owners are informed and experienced bidders in the free agent auction, but a few are not. Then most owners would only bid the true expected marginal revenue product of a player but the other inexperienced, uninformed bidders would bid well below or well above it. Under a steep competitive free agent auction, the highest of these inexperienced/uninformed bids will win. The winner will be cursed and player salaries will be well above their actual marginal revenue product. Contrary to this hypothesis, the winner's curse has not vanished after some first years of free agency when all teams became experienced in bidding. Free agent wage overpayment ${ }^{14}$ has not ceased (Zimbalist, 1992; Blecherman and Camerer, 1996) after years of free agency with experienced and well informed bidders, well aware of overpaying these players. Confirming Cassing and Douglas guesstimate, the winner's curse has been lasting in baseball though in a weaker form ${ }^{15}$. Another assumption is that the market for free agent players shares some features with a market for 'lemons'. Lehn (1984) found that owners lack all the information they need when they make bids and get stuck with injured players at a high price; the market for talent is subject to self selection of 'lemons'. Then the winner's curse occurs in a same way as in Akerlof's market for 'lemons' and results in an adverse selection of recruited players.

Moreover, a player's talent may be team-specific (Vrooman, 1996). Not only is the talent of the team-specific player asymmetrical or irreversible, but so is the knowledge about the team-

\footnotetext{
${ }^{14}$ Relatively to their marginal revenue product and to other players which are not free agents.

${ }^{15}$ Burger and Walters (2007) distinguish a "strong form" curse when the team winning the bid actually loses money and a "weak form" curse when winning bidders fail to use available information in formulating efficient bids and their returns have proven disappointing. Econometric testing with data on MLB free agents shows a strong form during the early years of free agency in the late 1970s, and a weak form in the late 1990s.
} 
specificity of the talent. The least incomplete information about the team-specificity of a player's talent resides with the owner (or general manager) of the team for which the player currently plays. The information about the team specificity of the player's talent is asymmetrically incomplete. Then the team for which the player has performed in the past seasons has more information about that player's future potential (or whether the player has health problems, is ill-natured or uneasy to coach for some reason) than other teams. The selling team is able to categorise its good and less good free agents while potential buying teams cannot. If buying teams fix their offer price on the expected value of the two types of players, then good players will never actually be sold, as the offer price will never reach the selling team's reservation price. The only players available in the market will be 'lemons': low quality players will drive good quality players out of the market. Only poor quality players will be traded at the reservation price.

However, in practice, one observes that good free agent players are traded but quite over the reservation price since potential buying teams have to bid one another for recruiting the best players. Eventually, systematic overbidding is due to free agent capacity of playing each bidding team against the others since each free agent player benefits of exclusivity rights over its talent and stands in a monopoly position in the market. This third assumption is in tune with the other explanations of the winner's curse (bidding for a sporting event, a sport franchise, or TV rights) but remains to be carefully tested.

A last question is to know whether the teams learned to behave in such a way as to eliminate the winner's curse. Econometric results (Burger and Walters, 2007) show that the winner's curse lasts though in a weak form in MLB while it seems to have disappeared after two years in NBA with regards to international player transfers (Eschker et al., 2004). Mistakes have been made by NBA teams when evaluating foreign players in the first years when such international transfers started after 1989. Foreign players earned salaries nearly $150 \%$ higher a 50\% salary bonus - than players trained in the U.S., as tested in the 1996-97 and 1997-98 seasons. North American teams were suffering from a lack of information regarding the true talent of international players. From the 1998 season on, there is no longer any significant difference in salaries between the two groups of players. As more international players entered the league, NBA teams committed increasing resources to scouting and gathering information about the comparative talent in the international basketball leagues and became able to better assess the players value. Hence the winner's curse vanished. Eschker et al. (2004) also found for any player - not only international players - that changing teams between seasons has a large negative impact on salaries; this suggests that between season 
player move may represent a market for 'lemons' in which there is still a possibility for a team to be cursed. It is in view of alleviating this possible effect that mercato slots $^{16}$ have been introduced in European (football) leagues.

\subsection{Overbidding in the arms' race for a superstar ends up in the red}

Although we distinguish it from the winner's curse in a bid for free agents, overbidding for a superstar player can drive any team into the winner's curse as well. Free agency is specific to North American team sports leagues as compared to European leagues where all players older than 18 are free to negotiate their contract since the Bosman ruling and where overbidding pertain to superstar players. However, free agency and superstar may overlap as a cause of the winner's curse as illustrated in the case of an MLB superstar ${ }^{17}$. In MLB, all the teams paid an average $\$ 2.8$ million to attract one superstar in 2007 , that is a $40 \%$ salary bonus, but they expected \$11 million of additional revenues from qualifying for the play offs (Krautman and Ciecka, 2009). Most of them were obviously wrong since by definition all teams cannot qualify for the play offs; and then were cursed.

The market for coaches in collegiate sports is also plagued with the winner's curse. The competitive process in which a superstar coach is hired is essentially auction-like; numerous bidders (universities) are vying against each other and no one wants to lose. The process clearly exhibits imperfect information about the future impact the superstar coach will have once he is hired and the additional revenue streams that will flow to the university (Grant $e t$ al., 2008).

The ultimate cause of the winner's curse is the arms' race between teams to recruit a superstar player or coach. The arms' race is more intense between teams in post-Bosman European (football) leagues than in North American leagues (Andreff, 2011), so that the winner's curse is more probable in the former than the latter market for superstars. The winner's curse has not been tested properly speaking for player movements in European (football) leagues. However, it is probably related to the so-called superstar effect empirically tested by Lucifora and Simmons (2003): a small number of players concentrate a

\footnotetext{
${ }^{16}$ Predefined periods of time (with a summer and a winter mercato) when player transfers (moves) are allowed and out of which transfers are forbidden.

17 "When Alex Rodriguez became a free agent while playing for the Seattle Mariners, several teams were interested in him. The Texas Rangers won the bidding, but it was widely reported that the $\$ 252$ million for ten years that the Rangers paid then the richest in team sports, was tens of millions of dollars more than they needed to pay in order to obtain Rodriguez's services" (Staudohar, 2012, p.110).
} 
disproportionate share of overall payroll in (Italian) football. Econometric testing shows that player salaries are convex in terms of performances exhibiting a superstar effect for players which are not perfectly substitutable when it comes to drawing attendances.

If one assumes that a superstar has a monopoly power over the rights on its scarce and imperfectly substitutable talent (Rosen, 1981), then demand-side competition in a global market for talent ${ }^{18}$ enables a superstar to capture a monopoly rent (Borghans and Groot, 1998); the latter more than countervails the monopsony power and rent of sports leagues and owners. The uniqueness of a superstar talent or image adds an exclusivity right to the usual right of using talent which diverts a part of the team's monopsony rent to the superstar monopolist. Signing David Beckham in 2007 LA Galaxy was suspected to be cursed; signing him in 2012, was Paris-Saint-Germain better off? But there is just one Beckham in the world. Eventually he has spent a short time on the pitch over the past season and has not scored that much. Was it worth paying him a monopoly rent basically in view of earning higher commercial revenues?

Overbidding for superstar players jeopardises a team's budget and its financial balance (Andreff, 2007) as it is witnessed with the current financial crisis of European professional football $^{19}$ and the data published by UEFA - $63 \%$ of European football clubs were in the red in 2011. A lasting and intense arms' race to recruit the best players has not faded away in European team sports leagues after 18 years of Bosman ruling. The bargaining power of a superstar is so high when facing the simultaneous demands of several competing teams that the bids' rise ends up with a salary higher than any credible and feasible level of marginal revenue product. Thus the superstar effect which is, on the team owner side, a "weak form" of the winner's curse turns out to be a "strong form" when, after transferring some superstars, the team budget falls in the red $^{20}$.

\footnotetext{
${ }^{18}$ An alternative explanation for this non equilibrium solution is an excess demand for superstar talents in a lasting disequilibrium market for talent (Andreff, 2014).

${ }^{19}$ See the Journal of Sports Economics 7 (1) 2006 and 8 (6) 2007 issues.

${ }^{20}$ A unique experience of using an actual auction to allocate players across teams is the one of the new cricket Indian Premier League (IPL) in January 2008. The new franchises needed to acquire players. With no history for any team, the IPL hit upon a novel way of assigning players to teams with an English auction. It was a phenomenon which was probably not understood much by some franchises. The winner's curse was at the corner. Parker et al. (2008) show that bidding outcomes exhibited an overvaluation of the most experienced players, namely those with an international experience acquired in Twenty 20 matches. The rules of the auction and the nature of the franchises triggered a salary bonus for Indian players. A greater bonus on younger Indian players was fuelled by the requirement that each team had four players under 22. The franchise owners were cursed.
} 


\subsection{Indices of a winner's curse in bids for free agents and superstars}

The winner's curse has a specific shape in team bids for scarce high quality talent. It is difficult to prove how much a league or team monopsony is countervailed by the exclusivity right of a player over its talent and which part of the monopsony rent is diverted to the player. A team is likely to be cursed when:

1. The number of bidding teams for a same player grows.

2. A player is significantly overpaid with a salary much higher than its marginal revenue product. This player has been able to bargain a salary overpayment or bonus through playing those teams that contemplate its recruitment against each other.

3. Acquiring a 'lemon' player who, after the bid, reveals to be in a bad shape, unhealthy, injured or has an unmanageable behaviour.

4. Disappointing returns on the bid, though the team does not lose money (the weak form of the winner's curse), or negative returns, i.e. financial loss after overbidding for a player (the strong form of the winner's curse).

5. A superstar effect that translates into a monopoly rent captured by a superstar player to the detriment of a team's budget is more often observed in the European than North American team sports leagues.

6. A team's financial deficit obviously due to an excess payroll, for instance a payroll/budget ratio higher than $100 \%$, when it is linked to recruiting some superstars without generating performances and revenues that cover salary overpayment.

\section{Insert Table 1 about here}

\section{Conclusion}

The winner's curse appears to be a major concept in sports economics. It corresponds to various sporting objects allocated through an auction or auction-like process, namely hosting mega-sporting events, attracting a professional sports team franchise, negotiating TV broadcasting rights over a sporting event, recruiting free agent and superstar players. In all circumstances, the seven above-listed preconditions of the winner's curse are there. Possibly one can find additional circumstances, for example in the sport betting and wagering industry or in the sporting goods industry. Avenues for further research on imperfect sports markets with asymmetric information may reveal that an additional number of them do function on an auction-like basis so that the winner's curse is likely to occur. For the time being, we have 
listed some indices that may confirm the very existence of the winner's curse in the four aforementioned auction or auction-like processes. A next step would be to define a metrics for all these indices - it is already done for some of them such as players' overpayment.

The only way that has been found so far to countervail and alleviate the winner's curse is to restrict competition on the demand side: collusion between bidding TV companies, merger, vertical integration, and toeholds in the face of a league's or team's monopoly over its broadcasting rights, and a player's monopoly over its talent rights. It may be time to raise the alternative issue: why not make the supply side of the market for sporting objects more competitive in breaking up sport monopolies? This is a taboo issue for all mega sporting event organisers from the IOC to FIFA, from MLB to NBA, from the English Premier League to UEFA, from a major league team in Seattle to another one in Philadelphia, and so on. This also opens an avenue for further hypothesizing.

\section{References:}

Akerlof, G. (1970), The Market for Lemons: Qualitative Uncertainty and the Market Mechanism, Quarterly Journal of Economics, 89, 488-500.

Andreff W. (1993), La crise des économies socialistes. La rupture d'un système, Grenoble: Presses Universitaires de Grenoble.

Andreff W. (2007), French Football: A Financial Crisis Rooted in Weak Governance, Journal of Sports Economics, 8 (6), 652-61.

Andreff W. (2011), Some comparative economics of the organization of sports: Competition and regulation in north American vs. European professional team sports leagues, European Journal of Comparative Economics, 8 (1), 3-27.

Andreff W. (2012a), Mondialisation économique du sport. Manuel de référence en Economie du sport, Bruxelles: De Boeck.

Andreff W. (2012b), The winner's curse: why is the cost of mega sporting events so often underestimated?, in

W. Maennig \& A. Zimbalist, eds, International Handbook on the Economics of Mega Sporting Events, Cheltenham: Edward Elgar, 37-69.

Andreff W. (2013), Crisis as Unexpected Transition ... to a Greed-Based Economic System, in: P. Zarembka, ed., Contradictions: Finance, Greed, Labor Unequally Paid, Research in Political Economy, vol. 28, Bingley: Emerald, 1-48.

Andreff W. (2014), Building Blocks for a Disequilibrium Model of a European Team Sports League, International Journal of Sport Finance, 9 (1), forthcoming.

Baade R. A., Baumann R.W., Matheson W.A. (2008), Assessing the Economic Impact of College Football Games on Local Economies, Journal of Sports Economics, 9 (6), 628-43.

Blair R.D. (2012), Sports Economics, Cambridge: Cambridge University Press. 
Blair J. and Swindell D. (1997), Sports, politics, and economics: The Cincinnati story, in: R.G. Noll \& A. Zimbalist, eds., Sports, Jobs, and Taxes: The Economic Impact of Sports Teams and Stadiums, Washington D.C.: The Brookings Institution, 282-323.

Blecherman B. and Camerer C.F. (1996), Is There a Winner's Curse in the Market for Baseball Players? Evidence from the Field, Social Science, Working paper 966, California Institute of Technology, Pasadena.

Borghans L. and Groot L. (1998), Superstardom and Monopoly Power: Why Media Stars Earn More than their Contribution to Welfare?, Journal of Institutional and Theoretical Economics, 154, 546-71.

Buraimo B. (2006), The Demand for Sports Broadcasting, in: W. Andreff \& S. Szymanski, eds., The Handbook on the Economics of Sport, Cheltenham: Edward Elgar, 100-111.

Burger J.D. and Walters S.J.K. (2007), The Existence and Persistence of a Winner's Curse: New Evidence from the (Baseball) Field, IASE-NAASE Working Papers Series, ${ }^{\circ}$ 06-25.

Capen, E., Clapp R. and Campbell W. (1971), Competitive bidding in high- risk situations, Journal of Petroleum Technology, 23, 641-53.

Cassing J. and Douglas R.W. (1980), Implications of the Auction Mechanism in Baseball's Free Agent Draft, Southern Economic Journal, 47, 110-21.

Cave M. and Crandall R.W., Sports Rights and the Broadcast Industry, Economic Journal, 111, 2001, F4-F26.

Coates D. (2007), Stadiums and Arenas: Economic Development or Economic Redistribution?, Contemporary Economic Policy, 25 (4), 565-77.

Dixit A. and B. Nalebuff (1991), Thinking Strategically: The Competitive Edge in Business, Politics, and Everyday Life, New York: W.W. Norton.

Dyker D. (1983), The Process of Investment in the Soviet Union, Cambridge: Cambridge University Press.

Eschker E., Perez S.J., Siegler M.V. (2004), The NBA and the Influx of International Basketball Players, Applied Economics, 36 (10), 1009-20.

Fort R. (2003), Sports Economics, Upper Saddle River: Prentice Hall.

Gilley, O., Karels G., Leone R. (1986), Uncertainty, experience and the winner's curse in OCS lease bidding, Management Science, 32, 673-82.

Grant R.R., Leadley J., Zygmont Z. (2008), The Economics of Intercollegiate Sports, Singapore: World Scientific Publishing.

Gratton C. and Solberg H.A. (2004), Sports and Broadcasting: Comparisons between the United States and Europe, in: R. Fort \& J. Fizel, eds., International Sports Economics Comparisons, Westport: Praeger, 175-87.

Gratton C. and Solberg H.A. (2007), The Economics of Sports Broadcasting, Abingdon: Routledge.

Harbord D., Binmore K. (2000), Toeholds, Takeovers and Football, European Competition Law Review, 21 (2), $1-4$.

Johnson B.K., Whitehead J.C. (2000), Value of Public Goods from Sports Stadiums: The CVM Approach, Contemporary Economic Policy, 18 (1), 48-58.

Kagel, J.H. and Levin D. (2002), Common Value Auctions and the Winner's Curse, Princeton, NJ: Princeton University Press.

Kornaï J. (1980), Economics of Shortage, Amsterdam: North Holland Publishing.

Krautmann A.C. and Ciecka J. (2009), The Postseason Value of an Elite Player to a Contending Team, Journal of Sports Economics, 10 (2), 168-79. 
Leeds, M. and von Allmen P. (2002), The Economics of Sports, Boston, MA: Addison Wesley.

Lehn K. (1984), Information Asymmetries in Baseball's Free Agent Market, Economic Inquiry, 22, 37-44.

Levis, M. (1990), The winner's curse problem, interest costs and the underpricing of initial public offerings', Economic Journal, 100, 76-89.

Lucifora C. and Simmons R. (2003), Superstar Effects in Sport: Evidence from Italian Soccer, Journal of Sports Economics, 4 (1), 35-55.

Parker D., Burn P., Natarajan H. (2008), Player Valuations in the Indian Premier League, Frontier Economics, October, 1-17.

Preuss H. and Schnitzer M. (2013), Organisation Costs for a FIFA World Cup and their Significance during a Bid, Working Paper Series Mainzer Papers on Sports Economics \& Management, $n^{\circ} 6$. Verifier reference, voir mail Preuss.

Quirk J., Fort R.D. (1999), Hard Ball: The Abuse of Power in Pro Team Sports, Princeton: Princeton University Press.

Rosen S. (1981), The Economics of Superstars, American Economic Review, 71, 845-58.

Rosentraub M.S. and Swindell D. (2002), Negotiating Games: Cities, Sports, and the Winner's Curse, Journal of Sport Management, 16, 18-35.

Sandy, R., Sloane P.J. and Rosentraub M.S. (2004), The Economics of Sports: An International Perspective, Basingstoke: Palgrave Macmillan.

Solberg H.A. (2006), The Auctioning of TV Sports Rights, International Journal of Sport Finance, 1 (1), 33-45.

Solberg H.A. and Hammervold R. (2008), TV Sports Viewers - Who Are They? A Norwegian Case Study, Nordicom Review, 29 (1), 95-110.

Staudohar P. (2012), The Reserve Clause and Labor Mobility, in: L.H. Kahane \& S. Shmanske, eds., The Oxford Handbook of Sports Economics Volume 1: The Economics of Sport, Oxford: Oxford University Press, 97-113.

Stotlar D.K. (2000), Vertical Integration in Sport, Journal of Sport Management, 14 (1), 1-7.

Sturgess B. and Brady C. (2006), Hosting the FIFA World Cup: Economic Boon or Winner's Curse, World Economics, 7 (4), 145-64.

Thaler, R.H. (1994), The Winner's Curse: Paradoxes and Anomalies of Economic Life, Princeton, NJ: Princeton University Press.

Vrooman J. (1996), The Baseball Players’ Labor Market Reconsidered, Southern Economic Journal, 63 (2), 339 60.

Vrooman J. (2000), The Economics of American Sports Leagues, Scottish Journal of Political Economy, 47 (4), 364-98.

Zimbalist 1992 compléter

\section{Appendix 1: Ex ante and ex post cost of Summer Olympics}

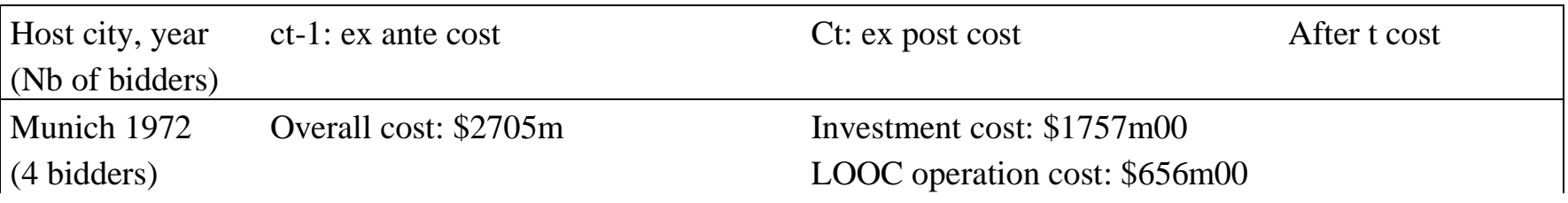




\begin{tabular}{|c|c|c|c|}
\hline $\begin{array}{l}\text { Montreal } 1976 \\
\text { ( } 3 \text { bidders) }\end{array}$ & $\begin{array}{l}\text { Investment cost: } \$ 549.5 \mathrm{~m} 00 \\
\text { Olympic stadium cost: } \$ 172 \mathrm{~m}\end{array}$ & $\begin{array}{l}\text { Investment cost: } \$ 3395.6 \mathrm{~m} 00 \\
\text { LOOC operation cost: } \$ 476 \mathrm{~m} 00\end{array}$ & $\begin{array}{l}\text { Operation: } \$ 1592 \mathrm{~m} \\
\text { Stadium: } \$ 1000 \mathrm{~m}\end{array}$ \\
\hline $\begin{array}{l}\text { Moscow } 1980 \\
\text { ( } 2 \text { bidders) }\end{array}$ & $\begin{array}{l}\text { Overall cost: } \$ 3.7 \mathrm{bn} \\
\text { Operation cost: } \$ 2 \mathrm{bn} \\
\text { Investment cost: } \$ 1,7 \mathrm{bn}\end{array}$ & Overall cost: $\$ 9 b n$ & \\
\hline $\begin{array}{l}\text { Los Angeles } \\
1984\end{array}$ & No commitment & $\begin{array}{l}\text { Overall cost: } \$ 1592 \mathrm{~m} \\
\text { LOOC operation cost: } \$ 546 \mathrm{~m}\end{array}$ & \\
\hline $\begin{array}{l}\text { Seoul } 1988 \\
(2 \text { bidders })\end{array}$ & $\begin{array}{l}\text { Overall cost: } \$ 3.1 \mathrm{bn} \\
\text { Investment cost: } \$ 3450 \mathrm{~m}\end{array}$ & $\begin{array}{l}\text { LOOCoperation cost: } \$ 664 \mathrm{~m} 00 \\
\text { Investment cost: } \$ 4063 \mathrm{~m} 00\end{array}$ & Extra cost: $\$ 2 b n$ \\
\hline $\begin{array}{l}\text { Barcelona } 1992 \\
\text { ( } 6 \text { bidders) }\end{array}$ & $\begin{array}{l}\text { Investment cost in: } \\
\text { 1985: F13bn; 1988: F23,5bn } \\
\text { 1990: F35,5bn; 1992: F41,5bn } \\
\text { LOOC operation cost: } \$ 1670 \mathrm{~m}\end{array}$ & $\begin{array}{l}\text { Investment cost: } \$ 10134 \mathrm{~m} 00 \\
\text { Overall cost: } \$ 9.3 \mathrm{bn} \\
\text { LOOC operation cost: } \$ 1793 \mathrm{~m} 00\end{array}$ & Debt: $\$ 6.1 \mathrm{bn}$ \\
\hline $\begin{array}{l}\text { Atlanta } 1996 \\
\text { ( } 6 \text { bidders) }\end{array}$ & Overall cost in 1990: $\$ 2021 \mathrm{~m}$ & $\begin{array}{l}\text { Investment cost: } \$ 1324 \mathrm{~m} 00 \\
\text { LOOC operation cost: } \$ 1346 \mathrm{~m} 00\end{array}$ & \\
\hline $\begin{array}{l}\text { Sydney } 2000 \\
\text { (5bidders) }\end{array}$ & $\begin{array}{l}\text { Overall cost in 1994: } \$ 3428 \mathrm{~m} \\
\text { Investment cost: } \$ 2500 \mathrm{~m} \\
\text { LOOC operation cost: } \$ 1463 \mathrm{~m} \\
\text { New South Wales Invt: } \$ 1220 \mathrm{~m}\end{array}$ & $\begin{array}{l}\text { Investment cost: } \$ 2601 \mathrm{~m} 00 \\
\text { LOOC operation cost: } \$ 2434 \mathrm{~m} 00 \\
\text { New South Wales Invt: } \$ 1249 \mathrm{~m}\end{array}$ & $\begin{array}{l}\text { Overall cost: } \\
\$ 6.6 \mathrm{bn}\end{array}$ \\
\hline $\begin{array}{l}\text { Athens } 2004 \\
\text { ( } 5 \text { bidders) }\end{array}$ & $\begin{array}{l}\text { LOOC operation cost: } \$ 2162 \mathrm{~m} 00 \\
\text { Overall cost: } € 4.6 \mathrm{bn}\end{array}$ & $\begin{array}{l}\text { LOOC operation cost: } \$ 2404 \mathrm{~m} 00 \\
\text { Overall cost: } € 6.0 \text { bn (June } 2004)\end{array}$ & Overall: €9.6bn \\
\hline $\begin{array}{l}\text { Beijing } 2008 \\
\text { ( } 5 \text { bidders })\end{array}$ & $\begin{array}{l}\text { Investment cost: } \$ 1600 \mathrm{~m} 00 \\
\text { Invt cost in 2006: } \$ 2800 \mathrm{~m} \\
\text { LOOC operation cost: } \$ 786 \mathrm{~m} 00 \\
\text { Olympic stadium cost: } € 300 \mathrm{~m} \\
\text { Overall cost: } € 2.2 \mathrm{bn}(\$ b n 1.9 \mathrm{bn}) 2004 \\
\$ 2.4 \mathrm{bn} \text { in } 2006\end{array}$ & $\begin{array}{l}\text { Investment cost: } \$ 2170 \mathrm{~m} 00 \\
\text { LOOC operation cost: } \$ 1458 \mathrm{~m} 00 \\
\text { Infrastructure cost: } \$ 35.6 \mathrm{bn} \\
\text { Olympic stadium cost: } € 380 \mathrm{~m} \\
\text { Overall cost: } \$ 43 \text { to } 45 \mathrm{bn}\end{array}$ & $\begin{array}{l}\text { Invt cost: } € 13.5 \mathrm{bn} \\
\text { Infrastr: } € 29 \mathrm{bn}\end{array}$ \\
\hline $\begin{array}{l}\text { London } 2012 \\
\text { ( } 5 \text { bidders })\end{array}$ & $\begin{array}{l}\text { Overall cost: } £ 3.4 \mathrm{bn} \text { in } 2005 \text {; } \\
£ 3.674 \mathrm{bn} \text { end } 2005 ; £ 9.3 \mathrm{bn} \text { in } 2007 \\
£ 10.0 \mathrm{bn} \text { in } 2009 \\
\text { Investment in } 2005: £ 2.664 \mathrm{bn} \\
\text { in } 2006: € 15.0 \mathrm{bn} \\
\text { LOOC operation } 2005: £ 1010 \mathrm{~m} \\
\text { in } 2006: € 1900 \mathrm{~m}\end{array}$ & $\begin{array}{l}\text { Overall in 2011: } \$ 19 \mathrm{bn} \\
(£ 11.6 \mathrm{bn})\end{array}$ & \\
\hline
\end{tabular}

m: million; bn: billion; \$m00: in 2000 dollars; Australian dollars for Sydney; F: French francs; $t$ is the date of the opening ceremony.

Excerpt from Andreff (2012b). 
Table 1: Indices of a winner's curse in sports auctions

\begin{tabular}{|l|l|l|l|}
\hline \multicolumn{1}{|c|}{ Mega sporting event } & \multicolumn{1}{c|}{ Hosting a team franchise } & \multicolumn{1}{c|}{ Bidding for broadcasting rigths } & \multicolumn{1}{c|}{ Overbidding for players } \\
\hline Cost overruns & Subsidies for new facilities & Swift TV rights fees increase & Growing number of bidders \\
Ex post project revisions & Luxurious increase in subsidies & TV company financial losses & Salary overpayment/bonus** \\
Delayed completion & Stadium cost overruns & TV company post-bid bankruptcy & Acquiring a 'lemon' player \\
Extra public subsidy & Slow economic growth & Sport event unknown details* & Bid disappointing return \\
Host city fiscal deficit / debt & Stagnating urban development & Outbidding newcomers & Superstar effect \\
Lower number of visitors & Lower attendance than expected & TV rights re-packaging & Team's deficit due to payroll \\
\hline
\end{tabular}

$*$ The future date, place and qualified teams or athletes.

** A wage higher than marginal revenue product may have different causes, including a lasting excess demand for superstars. 